\title{
Perencanaan Kebijakan Inventori Model Probabilistik Di CV. Bola Mas Pekanbaru
}

\author{
Wresni Anggraini ${ }^{1}$, Ferdyansyah ${ }^{1}$, \\ 1,2 Jurusan Teknik Industri, Fakultas Sains dan Teknologi, UIN Sultan Syarif Kasim Riau \\ Jl. HR. Soebrantas No. 155 Simpang Baru, Panam, Pekanbaru, 28293 \\ Email: wresni_anggraini@ymail.com,Ferdyansyah.fynn@gmail.com
}

\begin{abstract}
ABSTRAK
CV. Bola Mas merupakan perusahaan yang bergerak di bidang vulkanisir ban. Permasalahan yang terjadi di perusahaan ini adalah sering terjadinya stock out bahan baku yang menyebabkan terjadinya keterlambatan proses produksi. Hal ini terjadi karena tidak konstannya permintaan konsumen dan inventory lead time. Tujuan penelitian ini adalah memberikan usulan kebijakan sistem persediaan dengan model probabilistik yang dapat meminimasi keterlambatan produksi dengan biaya yang optimal. Berdasarkan analisis $\mathrm{ABC}$ terdapat 2 jenis bahan baku ragi ban yang akan dikendalikan yaitu jenis KG 1000-20 dan LG 1000-20. Metode Trend Projection digunakan untuk meramalkan permintaan konsumen dan mengetahui jumlah kebutuhan bahan baku yang diperlukan dalam proses produksi. Setelah membandingkan total biaya persediaan yang dihasilkan dari model probabilistik metode $\mathrm{P}$ dan metode $\mathrm{Q}$, maka diketahui metode $\mathrm{Q}$ adalah metode yang lebih optimal. Total ekspektasi biaya persediaan Rp. 2.702.151.080,-/tahun untuk ragi ban jenis KG 1000-20 dan Rp. 1.674.652.305,-/tahun untuk ragi ban jenis LG 1000-20
\end{abstract}

Kata kunci: Lead Time, ABC Analysis, Peramalan, Persediaan, Probabilistik.

\section{Pendahuluan}

Persediaan (inventory) merupakan komponen penting pada suatu industri. Dalam perusahaaan manufakturing, dibutuhkan persedian bahan baku ,produk jadi dan supplies. Perusahaan jasa industri seperti rumah sakit membutuhkan persediaan obat-obatan, bahan-bahan makanan, dan peralatan medis. Kantor-kantor pemerintahan membutuhkan persediaan bahan-bahan administrasi seperti kertas, blanko atau formulir, dan peralatan tulis lainnya. Item-item tersebut menjadi bukti bahwa persediaan merupakan objek yang penting bagi setiap sistem produksi yang harus selalu diperhatikan.

Menurut Heizer and Render, (dalam Wardana, 2014), persediaan merupakan sumber daya yang menganggur (idle resources), yang berarti jika persediaan berlebih akan menyebabkan investasi sia-sia, akan tetapi bila tidak ada persediaan akan sulit untuk mengantisipasi fluktuasi permintaan yang dapat menyebabkan terjadinya stockout. Sehingga diperlukan manajemen persediaan yang baik untuk mengatur keseimbangan antara investasi persediaan dan layanan pelanggan (service level).
CV. Bola Mas merupakan perusahaan yang bergerak di bidang vulkanisir ban. Vulkanisir Ban adalah suatu proses pelapisan ulang terhadap ban bekas. Tahapan dalam proses vulkanisir adalah menempel kembali bunga yang baru dengan sistem masak dingin atau curing dengan menggunakan temperature yang rendah agar tidak merusak casing ban itu sendiri melalui mesin Chamber untuk proses dingin sehingga ban tersebut kembali seperti ban baru.

Perusahaan ini merupakan tipe perusahaan produksi jasa dengan bahan baku produksi didapatkan dari agen-agen penyalur dan juga konsumen perseorangan, sedangkan perusahaan ini hanya akan menyediakan bahan baku tambahan seperti ragi ban, gum, linier dan bahan baku lainnya.

Terdapat 3 jenis ukuran ban yang menjadi komoditas produksi dari perusahaan ini yaitu ukuran 700-14, 750-16 dan 1000-20. Selama ini ban yang lebih banyak diterima oleh perusahaan untuk diolah adalah jenis ukuran 1000-20 yang digunakan oleh mobil truk fuso. Berikut merupakan data produksi masing-masing jenis ban dari $\mathrm{CV}$. Bola Mas: 
Tabel 1. Data produksi cv. bola mas bulan november 2015-oktober 2016

\begin{tabular}{|c|c|c|c|c|}
\hline No & Bulan & Jenis Ban & Kuantitas & Total \\
\hline \multirow{3}{*}{1} & \multirow{3}{*}{$\begin{array}{c}\text { November } \\
2015\end{array}$} & $700-14$ & 101 & \multirow{3}{*}{1680} \\
\hline & & $750-16$ & 207 & \\
\hline & & $1000-20$ & 1372 & \\
\hline \multirow{3}{*}{2} & \multirow{3}{*}{$\begin{array}{c}\text { Desember } \\
2015\end{array}$} & $700-14$ & 102 & \multirow{3}{*}{1611} \\
\hline & & $750-16$ & 212 & \\
\hline & & $1000-20$ & 1297 & \\
\hline \multirow{3}{*}{3} & \multirow{3}{*}{$\begin{array}{c}\text { Januari } \\
2016\end{array}$} & $700-14$ & 98 & \multirow{3}{*}{1573} \\
\hline & & $750-16$ & 173 & \\
\hline & & $1000-20$ & 1302 & \\
\hline \multirow{3}{*}{4} & \multirow{3}{*}{$\begin{array}{c}\text { Februari } \\
2016\end{array}$} & $700-14$ & 101 & \multirow{3}{*}{1666} \\
\hline & & $750-16$ & 188 & \\
\hline & & $1000-20$ & 1377 & \\
\hline \multirow{3}{*}{5} & \multirow{3}{*}{$\begin{array}{l}\text { Maret } \\
2016\end{array}$} & $700-14$ & 95 & \multirow{3}{*}{1622} \\
\hline & & $750-16$ & 185 & \\
\hline & & $1000-20$ & 1342 & \\
\hline \multirow{3}{*}{6} & \multirow{3}{*}{ April 2016} & $700-14$ & 104 & \multirow{3}{*}{1587} \\
\hline & & $750-16$ & 191 & \\
\hline & & $1000-20$ & 1292 & \\
\hline \multirow{3}{*}{7} & \multirow{3}{*}{ Mei 2016} & $700-14$ & 113 & \multirow{3}{*}{1631} \\
\hline & & $750-16$ & 187 & \\
\hline & & $1000-20$ & 1331 & \\
\hline \multirow{3}{*}{8} & \multirow{3}{*}{ Juni 2016} & $700-14$ & 95 & \multirow{3}{*}{1656} \\
\hline & & $750-16$ & 192 & \\
\hline & & $1000-20$ & 1369 & \\
\hline \multirow{3}{*}{9} & \multirow{3}{*}{ Juli 2016} & $700-14$ & 93 & \multirow{3}{*}{1598} \\
\hline & & $750-16$ & 183 & \\
\hline & & $1000-20$ & 1322 & \\
\hline \multirow{3}{*}{10} & \multirow{3}{*}{$\begin{array}{l}\text { Agustus } \\
2016\end{array}$} & $700-14$ & 88 & \multirow{3}{*}{1572} \\
\hline & & $750-16$ & 186 & \\
\hline & & $1000-20$ & 1298 & \\
\hline
\end{tabular}

(Sumber: CV. Bola Mas, 2016)

Berdasarkan data produksi CV. Bola Mas pada tabel 1 didapatkan bahwa hasil produksi didominasi oleh ban ukuran 1000-20. Pada Gambar 1.1 terlihat terjadi fluktuasi kuantitas hasil produksi pada periode November 2015 - Oktober 2016.

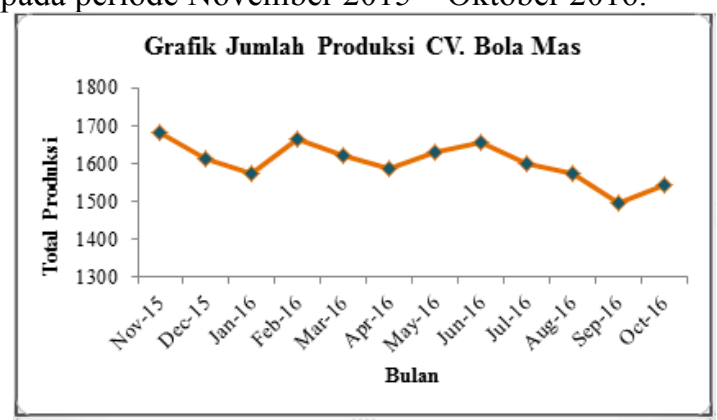

Gambar 1. Grafik jumlah produksi cv. bola mas nov 15okt 16

Terjadinya fluktuasi kuantitas produksi di perusahaan ini salah satunya disebabkan oleh adanya permintaan yang juga bersifat fluktuatif dari konsumen.. Selain fluktuasi dari permintaan yang terjadi di CV. Bola Mas, fluktuasi juga terjadi pada lead time ataupun waktu tunggu pemesanan bahan baku kepada supplier. Fluktuasi yang terjadi tentunya akan sangat menyulitkan manajemen perusahaan untuk dapat memperkirakan ataupun melakukan kebijakan yang tepat dalam upaya mengendalikan persediaan untuk dapat memenuhi kebutuhan produksi di perusahaan tersebut. Fluktuasi waktu tenggang dapat dilihat pada tabel 2.

Tabel 2. Lead time bahan baku bulan agustus - oktober

\begin{tabular}{|c|c|c|}
\hline Minggu Ke- & Bulan & $\begin{array}{c}\text { Lead time } \\
\text { (hari) }\end{array}$ \\
\hline 1 & \multirow{4}{*}{ Agustus } & 4 \\
\hline 2 & & 4 \\
\hline 3 & & 5 \\
\hline 4 & & 4 \\
\hline 1 & \multirow{4}{*}{ September } & 3 \\
\hline 2 & & 4 \\
\hline 3 & & 3 \\
\hline 4 & & 6 \\
\hline 1 & \multirow{4}{*}{ Oktober } & 5 \\
\hline 2 & & 5 \\
\hline 3 & & 4 \\
\hline 4 & & 5 \\
\hline
\end{tabular}

(Sumber: CV. Bola Mas, 2016)

Tabel 2. menunjukkan tidak konstannya waktu tenggang kedatangan bahan baku (lead time) , yang menyebabkan perusahaan sering mengalami kehabisan stok bahan baku ragi ban sebelum pesanan bahan baku yang baru tiba di gudang. Kebutuhan Ragi ban yang tidak dapat direncanakan dengan baik berdampak terhadap kelancaran proses produksi.

Berdasarkan pengamatan yang dilakukan pada perusahaan telah terjadi beberapa kasus keterlambatan produksi yang berimbas kepada keterlambatan pengiriman ban vulkanisir kepada konsumen, seperti pada tabel 3.

Berdasarkan data persediaan dan permintaan pada Tabel 3 didapatkan bahwa tidak mencukupinya persediaan ragi yang dimiliki oleh perusahaan yang didominasi oleh ragi $\mathrm{KG}$ ukuran 1000-20 yang menyebabkan permintaan dari lantai produksi tidak dapat terpenuhi. Permasalahan pada persediaan inilah yang menyebabkan keterlambatan waktu produksi yang berdampak kepada keterlambatan pengiriman kepada konsumen perseorangan. Tabel 4 menunjukkan frekuensi keluar masuknya ban yang berasal dari agen pemasok

Tidak adanya manajemen persediaan yang baik pada perusahaan menyebabkan tidak tercapainya ketepatan waktu produksi dan menurunnya kuantitas produksi. Dalam kondisi normal perusahaan dapat memproduksi maksimal 80 ban dalam sehari dalam 2 kali pemasakan, namun karena terjadinya stock out persediaan ragi ban, perusahaan ini hanya dapat memproduksi 40 ban dan hanya melakukan 1 kali pemasakan dalam 
buruk dari tidak adnya perencanaan persediaan yang baik adalah terhentinya kegiatan produksi secara total yang menyebabkan perusahaan tidak dapat melakukan proses pemasakan.

Tabel 3. Data Waktu input dan output ban vulkanisir cv. bola mas 14 november-30 november 2016

\begin{tabular}{|c|c|c|c|c|c|}
\hline $\begin{array}{c}\text { Tanggal } \\
\text { Kedatan } \\
\text { gan }\end{array}$ & Konsumen & $\begin{array}{c}\text { Jenis } \\
\text { Ban }\end{array}$ & Jmlh & $\begin{array}{l}\text { Tanggal } \\
\text { Keluar }\end{array}$ & Ket \\
\hline \multirow{3}{*}{$\begin{array}{c}\text { 14-Nov- } \\
16\end{array}$} & \multirow{2}{*}{ BKR } & $\begin{array}{l}1000- \\
20\end{array}$ & 88 & \multirow{2}{*}{ 17-Nov-16 } & \multirow{2}{*}{-} \\
\hline & & $\begin{array}{l}750- \\
16 \\
\end{array}$ & 12 & & \\
\hline & Bpk Im & $\begin{array}{l}750- \\
16 \\
\end{array}$ & 18 & 17-Nov-16 & - \\
\hline \multirow{3}{*}{$\begin{array}{c}\text { 16-Nov- } \\
16\end{array}$} & PT. RAP & $\begin{array}{l}1000- \\
20\end{array}$ & 19 & 18-Nov-16 & - \\
\hline & \multirow{2}{*}{ Gartindo V } & $\begin{array}{l}1000- \\
20 \\
\end{array}$ & 75 & \multirow{2}{*}{ 19-Nov-16 } & \multirow{2}{*}{-} \\
\hline & & $\begin{array}{l}750- \\
16 \\
\end{array}$ & 25 & & \\
\hline \multirow{4}{*}{$\begin{array}{c}\text { 17-Nov- } \\
16\end{array}$} & \multirow{2}{*}{ BKR } & $\begin{array}{l}1000- \\
20 \\
\end{array}$ & 95 & \multirow{2}{*}{ 23-Nov-16 } & \multirow{2}{*}{$\begin{array}{l}+2 \\
\text { hari }\end{array}$} \\
\hline & & $\begin{array}{l}750- \\
16\end{array}$ & 5 & & \\
\hline & Muaro B & $\begin{array}{l}1000- \\
20\end{array}$ & 25 & 23-Nov-16 & $\begin{array}{c}+2 \\
\text { hari }\end{array}$ \\
\hline & Wahana & $\begin{array}{l}700- \\
14 \\
\end{array}$ & 33 & 21-Nov-16 & \\
\hline \multirow{2}{*}{$\begin{array}{c}\text { 19-Nov- } \\
16\end{array}$} & \multirow{2}{*}{ Gartindo V } & $\begin{array}{l}1000- \\
20 \\
\end{array}$ & 85 & \multirow{2}{*}{$25-$ Nov-16 } & \multirow{2}{*}{$\begin{array}{l}+2 \\
\text { hari }\end{array}$} \\
\hline & & $\begin{array}{l}750- \\
16\end{array}$ & 15 & & \\
\hline \multirow{2}{*}{$\begin{array}{c}\text { 21-Nov- } \\
16\end{array}$} & Tunas 15 & $\begin{array}{l}700- \\
14\end{array}$ & 16 & 25 -Nov-16 & - \\
\hline & Bpk Zamri & $\begin{array}{l}1000- \\
20 \\
\end{array}$ & 8 & $25-N o v-16$ & - \\
\hline \multirow{2}{*}{$\begin{array}{c}\text { 23-Nov- } \\
16\end{array}$} & \multirow{2}{*}{ BKR } & $\begin{array}{l}1000- \\
20\end{array}$ & 90 & \multirow{2}{*}{ 26-Nov-16 } & \multirow{2}{*}{ - } \\
\hline & & $\begin{array}{l}750- \\
16 \\
\end{array}$ & 10 & & \\
\hline $\begin{array}{c}\text { 24-Nov- } \\
16\end{array}$ & $\begin{array}{l}\text { Bpk } \\
\text { Sahrial }\end{array}$ & $\begin{array}{l}750- \\
16\end{array}$ & 14 & 26-Nov-16 & - \\
\hline \multirow{2}{*}{$\begin{array}{c}\text { 25-Nov- } \\
16\end{array}$} & Gartindo V & $\begin{array}{l}1000- \\
20\end{array}$ & 80 & \multirow{2}{*}{$30-$ Nov-16 } & \multirow{2}{*}{$\begin{array}{c}+1 \\
\text { hari }\end{array}$} \\
\hline & & $\begin{array}{l}750- \\
16 \\
\end{array}$ & 20 & & \\
\hline \multirow{3}{*}{$\begin{array}{c}\text { 26-Nov- } \\
16\end{array}$} & BKR & $\begin{array}{l}1000- \\
20\end{array}$ & 77 & \multirow{2}{*}{ 01-Des-16 } & \multirow{2}{*}{$\begin{array}{c}+1 \\
\text { hari }\end{array}$} \\
\hline & & $\begin{array}{l}750- \\
16 \\
\end{array}$ & 23 & & \\
\hline & PT. SIR & $\begin{array}{l}750- \\
16 \\
\end{array}$ & 19 & 29-Nov-16 & - \\
\hline \multirow{2}{*}{$\begin{array}{c}\text { 28-Nov- } \\
16\end{array}$} & Alahan P & $\begin{array}{l}1000- \\
20 \\
\end{array}$ & 20 & - & - \\
\hline & Siagian & $\begin{array}{l}750- \\
16\end{array}$ & 10 & - & - \\
\hline \multirow{3}{*}{$\begin{array}{c}\text { 30-Nov- } \\
16\end{array}$} & Muaro B & $\begin{array}{l}1000- \\
20\end{array}$ & 33 & \multirow{2}{*}{ - } & \multirow{2}{*}{ - } \\
\hline & \multirow{2}{*}{ Gartindo V } & $\begin{array}{l}1000- \\
20\end{array}$ & 70 & & \\
\hline & & $\begin{array}{l}750- \\
16\end{array}$ & 30 & - & - \\
\hline
\end{tabular}

Tabel 4. Frekuensi keluar-masuk ban di cv. bola mas

\begin{tabular}{|c|c|c|}
\hline Agen Pemasok & Bulan & $\begin{array}{c}\text { Frekuensi Keluar- } \\
\text { Masuk Ban }\end{array}$ \\
\hline \multirow{3}{*}{ BKR } & Agustus & 8 kali \\
\cline { 2 - 3 } & September & 6 kali \\
\cline { 2 - 3 } & Oktober & 7 kali \\
\hline \multirow{2}{*}{ Gartindo V } & Agustus & 7 kali \\
\cline { 2 - 3 } & September & 7 kali \\
\hline
\end{tabular}

\section{\begin{tabular}{|l|l|l|}
\hline & Oktober & 8 kali \\
\hline
\end{tabular}}

(Sumber: CV. Bola Mas, 2016)

Permasalahan pada CV. Bola Mas ini tentunya harus dapat diselesaikan melalui manajemen produksi yang baik. Ketersediaan bahan baku yang memegang peran penting dalam kelancaran proses produksi pada perusahaan ini perlu direncanakan dengan baik.

Berdasarkan latar belakang diatas, maka penelitian ini bertujuan untuk menentukan berapa banyak bahan baku ragi ban yang dipesan dalam satu kali pemesanan, titik pemesanan kembali (ROP) bahan baku, interval pemeriksaan stok bahan baku yang tepat, serta dengan memperhitungkan safety stock persediaan yang bertujuan untuk mengantisipasi lead time pemesanan. Perhitunganperhitungan tersebut dilakukan dengan menggunakan metode Continuous Review System $(Q)$, Periodic Review System (P) untuk dapat membandingkan biaya persediaan yang optimal sebagai usulan bagi perusahaan

\section{Tinjauan Pustaka}

Persediaan didefinisikan suatu sumber daya menganggur (idle resources) yang keberadaannya menunggu proses lebih lanjut. Yang dimaksuddengan proses lebih lanjut dapat berupa kegiatan produksi seperti dijumpai pada system manufaktur, kegiatan pemasaran seperti yang dijumpai pada sistem distribusi, ataupun kegiatan konsumsi seperti dijumpai pada sistem rumah tangga, perkantoran dan sebagainya (Fathurohman, 2016). Beberapa pendapat mengenai pengertian dari persediaan adalah (Wardana dkk, 2014):

1. Persediaan adalah segala sesuatu atau sumber daya organisasi yang disimpan dalam antisipasinya terhadap pemenuhan permintaan baik internal maupun eksternal.

2. Persediaan adalah bagian utama dari modal kerja, merupakan aktiva yang pada setiap saat mengalami perubahan.

Inventory atau persediaan barang sebagai elemen utama dari modal kerja merupakan aktiva yang selalu dalam keadaan berputar, dimana secara terus-menerus mengalami perubahan (Wardana dkk, 2014).

Persediaan bisa muncul karena memang direncanakan atau merupakan akibat dari ketidaktahuan terhadap suatu informasi. Jadi ada perusahaan yang memiliki persediaan karena sengaja membuat produk lebih awal atau lebih banyak dari waktu dan jumlah yang akan dikirim atau dijual pada suatu waktu tertentu. Ada juga karena merupakan akibat dari permintaan yang terlalu sedikit dibandingkan dengan perkiraan awa (Wardana dkk, 2014). 
Berbeda dengan inventori deterministik yang selalu diketahui dengan pasti permintannya, dalam inventori probabilistk permintaan tidak pasti dan berflukuasi sesuai dengan kebutuhan konsumennya, walaupun semikian ketidakpastian ini memiliki pola tertentu yang dicirikan dengan nilai sentral, nilai sebaran dan pola distribusinya yang dapat diprediksi (Bahagia, 2006).

Dalam kehidupan sehari-hari sering dijumpai fenomena inventori probabilistik, dalam sistem inventori ketidakpastian dapat berasal dari (Bahagia, 2006):

1. Pemakai (user) yang berupa fluktuasi permintaan yang dicerminkan oleh variansi atau deviasi standarnya $(S)$

2. Pemasok (supplier) yang berupa ketidaktepatan waktu pengiriman barang yang dicerminkan oleh waktu ancang-ancang (lead time $L$ )

3. System manajemen yang berupa ketidakhandalan pengelola dalam menyikapi permasalahan yang dicerminkan dengan factor resiko yang mampu ditanggung $\left(Z_{\alpha}\right)$.

Ketidakpastian yang dimaksud disini bukan bersifat acak tetapi dengan pola distribusi keungkinan yang diketahui. Secara statistik fenomena probabilistic adalah fenomena yang dapat diprediksi parameter populasinya baik ekspektasi, variansi, maupun pola distribusi kemungkinannya. Adanya fenomena probabilistic didalam system inventori mengakibatkan pengelolaannya menjadi lebih sulit bila dibandingkan dengan system invenori deterministic, sebab dengan adanya fenomena ketidakpasian akan menyebabkan timbulnya variansi yag merupakan sumber penyimpangan dari rencana yang telah dibuat (Bahagia, 2006).

Sebagaimana model probabilistik sederhana, permasalahan kebijakan inventori yang akan dipecahkan dengan model inventori probabilistik $Q$ (model $Q$ ) berkaitan dengan penentuan besarnya stok operasi (operating stock) dan cadangan pengamannya (safety stock). Secara lebih spesifik permasalahan pokok ini dijabarkan ke dalam tiga pertanyaan dasar yang akan menjadi fokus untuk dijawab di dalam model ini, yaitu (Bahagia, 2006):

1. Berapa jumlah barang yang akan dipesan untuk setiap kali pemesanan dilakukan $\left(q_{0}\right)$ ?

2. Kapan saat pemesanan dilakukan (r) ?

3. Berapa besarnya cadangan pengaman (ss) ?

Sebagaimana pada model $Q$, permasalahan kebijakan inventori yang akan dipecahkan dengan model $P$ berkaitan dengan penentuan besarnya stok operasi (operating stock) yang hars disediakan dan cadangan pengamannya. Secara lebih spesifik permasalahan pokok ini dijabarkan ke dalam tiga pertanyaan dasar yang akan menjadi fokus untuk dijawab di dalam model ini, yaitu (Bahagia, 2006):

1. Berapa jumlah barang yang akan dipesan untuk setiap kali pemesanan dilakukan?

2. Kapan saat pemesanan dilakukan?

3. Berapa besarnya cadangan pengaman?

Salah satu hal yang menyulitkan perhitungan peramalan adalah fluktuasinya aktifitas permintaan sepanjang waktu. Sangat jarang dijumpai bahwa permintaan itu bersifat konstan dan merata sepanjang masa. Dari segi fluktuasi ini, pola permintaan dapat dibagi menjadi beberapa jenis, yaitu kecendrungan (trend), Horizontal (Stationer) musiman (seasonal), siklikal, (cyclical), dan tak teratur (irregular) (Indrajit dkk, 2003).

1. Kecendrungan (trend)

2. Variasi musiman (seasonal variation)

3. Variasi siklikal (cyclical variation)

4. Pola Horizontal

\section{Metode Penelitian}

\section{Penentuan Prioritas Pengendalian Bahan Baku}

Penentuan prioritas bahan baku yang akan dikendalikan menggunakan metode ABC. Metode ABC mengelompokkan bahan baku berdasarkan harga dan kuantitas penggunaan bahan baku. Prioritas pengendalian bahan baku terpilih merupakan jenis bahan baku yang termasuk dalam kelas A. Langkah pengolahan ini dilakukan dengan memanfaatkan fungsi Inventory ABC Analysis pada Software QM For Windows V4. Berdasarkan analisis $\mathrm{ABC}$, diperoleh 2 jenis bahan baku yang menjadi prioritas untuk dikendalikan, terlihat pada tabel 5.

Tabel 5. Pengkategorian jenis ragi

\begin{tabular}{|l|c|}
\hline \multicolumn{1}{|c|}{ Jenis Ragi } & Kategori \\
\hline KG 1000-20 & A \\
\hline LG 1000-20 & A \\
\hline AS 1000-20 & B \\
\hline AS 750-16 & C \\
\hline AT 750-16 & C \\
\hline HB 750-16 & B \\
\hline LG 750-16 & B \\
\hline KG 750-16 & C \\
\hline HW 750-16 & B \\
\hline HW 700-14 & C \\
\hline LG 700-14 & C \\
\hline KBA 700-14 & C \\
\hline KFC 700-14 & C \\
\hline
\end{tabular}

(Sumber: Pengolahan Data, 2017)

Berdasarkan Tabel 5 yang merupakan rekapitulasi pengkategorian analisis $\mathrm{ABC}$, terlihat 
jenis ragi yang berada dalam kategori A adalah ragi jenis KG 1000-20 dan LG 1000-20. Dua jenis ragi ini akan menjadi prioritas untuk dikendalikan persediaannya

\section{Identifikasi Pola Data Historis Permintaan Ragi}

Pengidentifikasian pola data permintaan ragi ban digunakan sebagai landasan dalam pemilihan metode peramalan yang sesuai terhadap dua jenis ragi ban prioritas.

Berdasarkan data permintaan ragi ban jenis KG 1000-20 dan LG 1000-20 akan didapatkan pola data yang diplotkan dalam bentuk grafik, pada gambar 2 dan 3 .

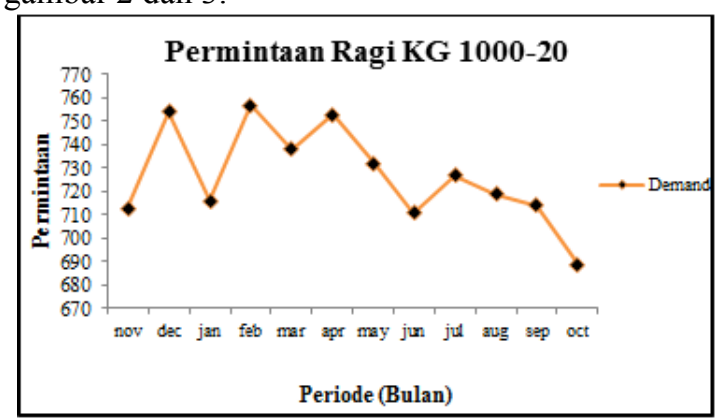

Gambar 2. Permintaan KG 1000-20

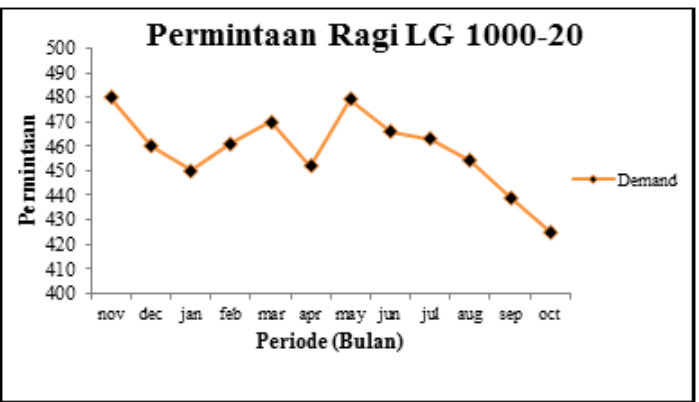

Gambar 3. Permintaan LG 1000-20

Berdasarkan plot data yang terlihat pada Gambar 3.1 dan 3.2 yang menunjukkan pola data berfluktuasi serta mengandung trend penurunan. Sedangkan untuk data yang bersifat demikian dapat digunakan metode peramalan Eksponential Smoothing with trend dan metode Trend Projection dimana kedua metode ini lebih cocok digunakan untuk memproyeksikan data yang berfluktuasi serta mengandung pola trend. Pada penelitian ini metode peramalan terpilih adalah Trend Projection, karena menghasilkan error yang lebih kecil.

\section{Peramalan Permintaan Baha Baku Ragi}

1. Peramalan Permintaan Ragi Jenis KG 1000-20

$$
\begin{aligned}
& Y=a+b x \\
& b=\frac{n \Sigma x y-\Sigma x \Sigma y}{n \Sigma x^{2}-(\Sigma x)^{2}}
\end{aligned}
$$

$$
\begin{aligned}
& \mathrm{b}=\frac{12(56272)-(78)(8723)}{12(650)-(78)^{2}} \\
& \mathrm{~b}=\frac{675264-680394}{7800-(6084)} \\
& \mathrm{b}=\frac{-513 \mathrm{C}}{1716} \\
& \mathrm{~b}=-2,99 \\
& \mathrm{a}=\frac{\Sigma \mathrm{y}-\mathrm{b} \Sigma}{\mathrm{n}} \\
& \mathrm{a}=\frac{8723-(-2,99)(78)}{12} \\
& \mathrm{a}=746,350
\end{aligned}
$$

Jadi, $\mathrm{Y}=\mathrm{a}+\mathrm{bx}$ sehingga persamaan yang didapatkan adalah $\mathrm{Y}=746,350-2,99 \mathrm{X}$

Tabel 6. Tabel hasil peramalan metode trend projection KG 1000-20

\begin{tabular}{|l|c|c|}
\hline \multicolumn{1}{|c|}{ Periode (Bulan) } & $\boldsymbol{x}$ & $\begin{array}{c}\text { Forecast } \\
(\mathbf{Y = 7 4 6 , 3 5 0}-\mathbf{2 , 9 9} \boldsymbol{x})\end{array}$ \\
\hline November 2016 & 13 & 708 \\
\hline Desember 2016 & 14 & 705 \\
\hline Januari 2017 & 15 & 702 \\
\hline Februari 2017 & 16 & 699 \\
\hline Maret 2017 & 17 & 696 \\
\hline April 2017 & 18 & 693 \\
\hline Mei 2017 & 19 & 690 \\
\hline Juni 2017 & 20 & 687 \\
\hline Juli 2017 & 21 & 684 \\
\hline Agustus 2017 & 22 & 681 \\
\hline September 2017 & 23 & 678 \\
\hline Oktober 2017 & 24 & 675 \\
\hline
\end{tabular}

(Sumber: Pengolahan Data, 2017)

2. Peramalan Permintaan Ragi Jenis LG 1000-20

$$
\begin{aligned}
& Y=a+b x \\
& b=\frac{n \Sigma x y-\Sigma x \Sigma y}{n \Sigma x^{2}-(2 x)^{2}} \\
& b=\frac{12(35373)-(78)(5499)}{12(650)-(78)^{2}} \\
& b=\frac{424476-42892}{7800-(6084)} \\
& b=\frac{-444 t}{1716} \\
& b=-2,591 \\
& a=\frac{\Sigma y-b \Sigma}{n} \\
& a=\frac{5499-(-2,591)(78)}{12} \\
& a=475,091
\end{aligned}
$$

Jadi, $Y=a+b x$ sehingga persamaan yang didapatkan adalah $\mathrm{Y}=475,091-2,591 \mathrm{X}$ 
Tabel 7. Hasil Peramalan metode Trend Projection LG $1000-20$

\begin{tabular}{|l|c|c|}
\hline Periode (Bulan) & $\boldsymbol{x}$ & $\begin{array}{c}\text { Forecast } \\
(\mathbf{Y = 4 7 5 , 0 9 1} \mathbf{- 2 , 5 9 1 x )}\end{array}$ \\
\hline November 2016 & 13 & 442 \\
\hline Desember 2016 & 14 & 439 \\
\hline Januari 2017 & 15 & 437 \\
\hline Februari 2017 & 16 & 434 \\
\hline Maret 2017 & 17 & 432 \\
\hline April 2017 & 18 & 429 \\
\hline Mei 2017 & 19 & 426 \\
\hline Juni 2017 & 20 & 424 \\
\hline Juli 2017 & 21 & 421 \\
\hline Agustus 2017 & 22 & 419 \\
\hline September 2017 & 23 & 416 \\
\hline Oktober 2017 & 24 & 413 \\
\hline
\end{tabular}

(Sumber: Pengolahan Data, 2017)

\section{Perencanaan Pengendalian Persediaan Bahan Baku Ragi Prioritas}

1. Perencanaan Pengendalian Persediaan Bahan Baku Ragi KG 1000-20

a. Perhitungan dengan pendekatan sistem continuous review system $(Q)$

Berdasarkan perhitungan Kebijakan inventori optimal, yaitu:

$\mathrm{q}_{0}=643,34$ roll dibulatkan menjadi 644 roll $\mathrm{r}=99,23$ roll dibulatkan menjadi 100 roll ss $=7,95$ roll, dibulatkan menjadi 8 roll

Ekspektasi ongkos total per tahun:

$$
\begin{aligned}
\mathrm{O}_{\mathrm{T}}= & \mathrm{Dp}+\frac{\mathrm{AD}}{q_{0}}+\mathrm{h}\left(\frac{q_{0}}{2}+\mathrm{r}-\mathrm{D}_{\mathrm{L}}\right)+ \\
& \mathrm{c}_{\mathrm{u}} \frac{\mathrm{D}}{q_{\mathrm{a}}} \int_{\mathrm{I}}^{\infty}(\mathrm{x}-\mathrm{r}) \mathrm{f}(\mathrm{x}) \mathrm{dx} \\
= & 8.298 \times 323.200+\frac{(761.000)(8.298 ;}{643,34} \\
+ & 31.130 \\
& \left(\frac{(643,34)}{2}+99,23-8298 \times 0,011\right)+ \\
& \frac{(1 \supset 9.000)(8298 ;}{643,34} \times 0,09 \\
= & 2.681 .913 .600+9.815 .616+ \\
& 10.247 .289+184.575 \\
& \mathrm{O}_{\mathrm{T}}=\text { Rp. } 2.702 .151 .080,-/ \text { tahun }
\end{aligned}
$$

\section{b. Perhitungan dengan pendekatan sistem Periodic review system $(P)$}

Tabel 8. Hasil perhitungan $\mathrm{T}$ dan $\mathrm{R}$ untuk ragi jenis $\mathrm{KG}$ 1000-20

\begin{tabular}{|c|c|c|c|l|}
\hline $\begin{array}{c}\text { T } \\
\text { (tahun) }\end{array}$ & $\begin{array}{c}\text { R } \\
\text { (roll) }\end{array}$ & $\begin{array}{c}\text { Ss } \\
\text { (roll) }\end{array}$ & $\begin{array}{c}\mathbf{O}_{\mathrm{T}} \\
\text { (Rp/tahun) }\end{array}$ & Ket \\
\hline 0,1155 & $\begin{array}{c}1.07 \\
6,2\end{array}$ & 26,5 & $\begin{array}{c}\mathrm{Rp} 2.734 . \\
693.811,-\end{array}$ & \\
\hline 0,077 & $\begin{array}{c}754, \\
11\end{array}$ & 23,88 & $\begin{array}{c}\text { Rp. } \\
2.722 .933 .446,-\end{array}$ & \\
\hline 0,0385 & $\begin{array}{c}431, \\
15\end{array}$ & 20,4 & $\begin{array}{c}\text { Rp. } \\
2.717 .690 .728,-\end{array}$ & Opt \\
\hline 0,01925 & $\begin{array}{c}268, \\
51\end{array}$ & 17,5 & $\begin{array}{c}\text { Rp. } \\
2.729 .851 .995,-\end{array}$ & \\
\hline
\end{tabular}

(Sumber: Pengolahan Data, 2017)

$$
\begin{aligned}
& \text { Dengan demikian kebijakan optimal adalah: } \\
& \mathrm{T} \quad=0,0385 \text { bulan atau } 14 \text { hari } \\
& \mathrm{R} \quad=431,15 \text { roll dibulatkan menjadi } 432 \text { roll } \\
& \mathrm{ss} \quad=20,4 \text { roll dibulatkan menjadi } \\
& \quad 21 \text { roll }
\end{aligned}
$$

2. Perencanaan Pengendalian Persediaan Bahan Baku Ragi LG 1000-20

a. Perhitungan dengan pendekatan sistem continuous review system $(Q)$

Berdasarkan perhitungan Kebijakan inventori optimal, yaitu:

$\mathrm{q}_{0}=507,2$ roll dibbulatkan menjadi 508roll

$\mathrm{r}=63,38$ roll dibulatkan menjadi 64 roll

ss $\quad=6,93$ roll, dibulatkan menjadi 7 roll

Sedangkan Ekspektasi ongkos total per tahun:

$$
\begin{aligned}
& 0_{T}=D p+\frac{A D}{q_{0}}+h\left(\frac{q_{0}}{2}+r-D_{L}\right)+c_{u} \frac{D}{q_{a}} \\
& \int_{r}^{\infty}(x-r) f(x) d x \\
& =5132 \times 323.200+\frac{(761.000)(5132)}{508} \\
& +31.123\left(\frac{(508)}{2}+64-5132 \times 0,011\right) \\
& +\frac{(159.000)(5132)}{508} \times 0,113 \\
& =` 1.658 .662 .400+7.678 .898+8.129 .498 \\
& +181.509 \\
& 0_{T}=\text { Rp. } 1.674 .652 .305,-/ \text { tahun }
\end{aligned}
$$

b. Perhitungan dengan pendekatan sistem Periodic review system $(P)$

Tabel 9. Hasil Perhitungan T dan R Untuk Ragi jenis LG 1000-20

\begin{tabular}{|c|c|c|c|c|c|}
\hline $\begin{array}{c}\mathbf{T} \\
\text { (tahun) }\end{array}$ & $\begin{array}{c}\mathbf{R} \\
\text { (roll) }\end{array}$ & $\begin{array}{c}\text { ss } \\
\text { (roll) }\end{array}$ & $\begin{array}{c}\mathbf{n n} \\
\text { (roll) }\end{array}$ & $\mathbf{O}_{\mathrm{T} \text { (Rp) }}$ & $\begin{array}{c}\mathbf{K e} \\
\mathbf{t}\end{array}$ \\
\hline
\end{tabular}




\begin{tabular}{|c|c|c|c|c|c|}
0,09 & 540 & 21,67 & 0,3 & $\begin{array}{c}\mathrm{Rp} \\
1.689 .85 \\
5.734,-\end{array}$ & \\
\hline 0,135 & $\begin{array}{c}774,6 \\
5\end{array}$ & 25,38 & 0,4 & $\begin{array}{c}\mathrm{Rp} \\
1.697 .86 \\
0.756,-\end{array}$ & \\
\hline 0,045 & $\begin{array}{c}304,0 \\
9\end{array}$ & 16,7 & 0,122 & $\begin{array}{c}\mathrm{Rp} .1 .68 \\
7.290 .70 \\
0,-\end{array}$ & $\begin{array}{c}\text { Op } \\
\mathbf{t}\end{array}$ \\
\hline & $\begin{array}{c}185,0 \\
0,0225\end{array}$ & 13,17 & 0,04 & $\begin{array}{c}\mathrm{Rp} \\
1.698 .56 \\
0.040,-\end{array}$ & \\
\hline
\end{tabular}

Dengan demikian kebijakan optimal adalah:

$$
\begin{array}{ll}
\mathrm{T} & =0,045 \text { tahun atau } 17 \text { hari } \\
\mathrm{R} & =304,09 \text { roll dibulatkan menjadi } 305 \text { roll } \\
\mathrm{Ss} & =16,7 \text { roll dibulatkan menjadi } 17 \text { roll }
\end{array}
$$

\section{Hasil dan Pembahasan}

Berdasarkan rekapitulasi pengkategorian analisis $\mathrm{ABC}$, terlihat jenis ragi (tread linear) yang berada dalam kategori A adalah ragi jenis KG 100020 dan LG 1000-20. Dua jenis ragi ini akan menjadi prioritas untuk dikendalikan persediaannya. Berdasarkan pola data permintaan kedua jenis ragi ban, diketahui bahwa data bersifat fluktuasi serta mengandung trend.

Pemesanan bahan baku dengan menggunakan sistem $\mathrm{Q}$ untuk bahan Baku ragi ukuran KG 1000-20 dengan ekspektasi total biaya persediaan (Tc) sebesar Rp. 2.702.151.080, -/tahun. Pemesanan bahan baku dengan menggunakan sistem $\mathrm{P}$ untuk bahan Baku ragi ukuran KG 100020 dengan ekspektasi total biaya persediaan (Tc) sebesar Rp 2.717.690.728,-- pertahun.

Pemesanan bahan baku dengan menggunakan sistem $\mathrm{Q}$ untuk bahan Baku ragi ukuran LG 1000-20 dengan ekspektasi total biaya persediaan (Tc) sebesar Rp.1.674.652.305,- /tahun. Pemesanan bahan baku dengan menggunakan sistem P untuk bahan Baku ragi ukuran LG 1000-20 dengan ekspektasi total biaya pengadaan (Tc) sebesar Rp 1.687.290.700,-pertahun.

\section{Kesimpulan}

Berdasarkan hasil pengolahan data maka dapat ditarik kesimpulan bahwa metode pengendaliaan persediaan bahan baku yang paling optimal di CV. Bola Mas adalah metode Continuous review system atau system Q. Untuk bahan Baku ragi ukuran KG 1000-20 ekspektasi total biaya persediaan (Tc) sebesar Rp. 2.702.151.080, -/tahun. Untuk bahan Baku ragi ukuran LG 1000-20 dengan ekspektasi total biaya persediaan (Tc) sebesar Rp.1.674.652.305,- /tahun.

\section{Daftar Pustaka}

[1] Arsyad, Lincoln. "Peramalan Bisnis". Edisi 1, BPFE-Yogyakarta, Yogakarta, 1994.

[2] Asssauri, Sofjan. "Management Produksi". Lembaga Penerbit Fakultas Ekonomi Universitas Indonesia, Jakarta, 1980.

[3] Bagshaw, Karibo B. "Lead Time Uncertainties, Average Inventory and Scheduling Practice on Manufacturing Firms in Nigeria". International Review of Management and Business Research Vol. 4 Issue.4. Department of Management Rivers State University of Science and Technology Port Harcourt. Nigeria, 2015.

[4] Bahagia, Nur Senator. "Sistem Inventori". ISBN 979-3507-89-6. Penerbit ITB, Bandung, 2006.

[5] Dristiana, Fila dan Sukmono Tedjo. "Pengendalian Persediaan Bahan Baku Obat Dengan Menggunakan Metode EOQ Probabilistik Berdasarkan Peramalan Exponential Smoothing Pada PT. XYZ”. Jurnal Spektrum Industri, Vol. 13, No. 2, 115 - 228, ISSN : 1963-6590. Program Studi Teknik Industri, Universitas Muhammadiyah. Sidoarjo, 2015.

[6] Fathurohman. "Usulan Penerapan Metode Persediaan Probabilistik Untuk Menghitung Kebutuhan Bahan Baku Di PT. Megayaku Kemasan Perdana Karawang”. Jurnal Buana Ilmu, Vol. 1, No. 1, ISSN: 2541 - 6995. Universitas Buana Perjuangan. Karawang, 2016.

[7] Fithri, Prima dan Sindikia Annise. "Pengendalian Persediaan Pozzolan Di PT Semen Padang". Jurnal Optimasi Sistem Industri, Vol. 13 No. 2, ISSN 2088-4842. Jurusan Teknik Industri, Fakultas Teknik, Universitas Andalas. Padang, 2014.

[8] Gaspersz, Vincent. "Production Planning and Inventory Control". PT Gramedia Pustaka Utama, Jakarta, 1998.

[9] Nurhasanah, Nunung. "Perencanaan Pengendalian Produksi Dan Persediaan Industri Pasta PT XYZ”. Jurnal INASEA, Vol. 6 No. 2. Jurusan Teknik Industri, Fakultas Teknik, UbiNus. Jakarta, 2005. Available http://journal.binus.ac.id. Diakses pada 19 April 2017.

[10] Indrajit, Richardus Eko dan Djokopranoto Richardus. "Manajemen Persediaan". PT Grasindo, Jakarta, 2003. 
[11] Nasution, Arman Hakim dan Yudha Prasetyawan. "Perencanaan dan Pengendalian Produski”. Graha Ilmu, Yogyakarta, 2008.

[12] Pawitan, Gandhi dan Paramasatya Amithya. "Aplikasi Analisis Pareto Dalam Pengendalian Inventori Bahan Baku Pada Bisnis Restoran”. Jurnal Administrasi Bisnis, Vol.4, No.1: Hal. 80-96, ISSN:0216-1249. Jurusan Ilmu Administrasi Bisnis, Fakultas Ilmu Sosial dan Ilmu Politik, Universitas Katolik Parahyanga. Bandung, 2008.

[13] Rangkuti, Freddy. "Manajemen Persediaan Aplikasi di Bidang Bisnis". PT Raja Grafindo Persada, Jakarta, 2015.

[14] Ristono, Agus. "Manajemen Persediaan". Graha Ilmu, Yogyakarta, 2013.

[15] Sinulingga, Sukaria. "Pengantar Teknik Industri”. Graha Ilmu, Yogyakarta, 2008.

[16] Susanto, Kurniawan dan Gunadhi Erwin. “ Pengendalian Persediaan Bahan Baku Lilin
Dengan Model Probabilistic Q’. Jurnal Kalibrasi Vol. 11 No. 1, ISSN : 2302-7312. Sekolah Tinggi Teknologi Garut, Garut, 2013.

[17] Waters, Donald. "Inventory Control and Management". Wiley, Great Britain, 2003.

[18] Wardana, Marcelly Widya, Saleh Farham HM dan Ali Parkhan. "Pengendalian Persediaan Pada Kondisi Stokastik Dan Harga Bertingkat Menggunakan Simulasi”. Jurnal Spektrum Industri Vol. 12, No. 2, Hal $113-247$, ISSN : 1963-6590. Jurusan Teknik Industri, Universitas Islam Indonesia, Yogyakarta, 2014.

[19] Wardhani, Parwita Setya. "Perencanaan dan Pengendalian Persediaan dengan Metode EOQ". Jurnal Media Mahardhika Vol. 13 No. 3. STIE Mahardhika. Surabaya, 2015.

[20] Yusuf, Abduk Mumini. "Inventory Control And Economic Order Quantity In National Electric Power Authority (Nepa)". Jurnal Universitas St Clements. Turki, 2003. 